\title{
Dietary Effect of Corchorus olitorius Seeds on Growth Performance of Oreochromis niloticus Fingerlings
}

\author{
Oluwafumilola Eunice Afe ${ }^{1, *}$, Adekunle Ayokanmi Dada ${ }^{1}$, Muhammed Lawal \\ Salihu ${ }^{1}$
}

${ }^{1}$ The Federal University of Technology, School of Agriculture and Agricultural Technology, Department of Fisheries and Aquaculture Technology, Akure, PMB 704, Akure, Ondo State, Nigeria.

How to cite

Afe, O.E., Dada, A.A., Salihu, M.L. (2021). Dietary Effect of Corchorus olitorius Seeds on Growth Performance of Oreochromis niloticus Fingerlings. Aquaculture Studies, 21, 101-107. http://doi.org/10.4194/2618-6381-v21_3_02

\section{Article History}

Received 20 November 2020

Accepted 24 February 2021

First Online 23 March 2021

Corresponding Author

Tel.: +2348100031354

E-mail: oeaguda@futa.edu.ng

\section{Keywords}

Oreochromis niloticus

Corchorus olitorius

Growth performance

Haematological parameters

\begin{abstract}
Incorporating feed additives in diets of cultured fish is aimed at improving growth performance, immunity and carcass quality. Growth performance and some haematological parameters of Oreochromis niloticus fingerlings fed varying inclusion levels of Corchorus olitorius seeds were assessed in the study. $O$. niloticus fingerlings of initial mean weight $9.35 \pm 0.01 \mathrm{~g}$ were evaluated for a period of 56 days. Five experimental diets were formulated at varying inclusion levels; $0 \mathrm{~g} / 100 \mathrm{~g}$ (control), $0.5 \mathrm{~g} / 100 \mathrm{~g}, 1.0 \mathrm{~g} / 100 \mathrm{~g}, 1.5 \mathrm{~g} / 100 \mathrm{~g}$ and $2.0 \mathrm{~g} / 100 \mathrm{~g}$ of $C$. olitorius seeds. All diets were isonitrogenous with each treatment having triplicates. $O$. niloticus fingerlings fed $1.5 \mathrm{~g} / 100 \mathrm{~g}$ diet $\mathrm{C} C$. olitorius recorded the best growth performance in terms of weight gain, feed conversion ratio (FCR) and specific growth rate (SGR). There was a significant increase in growth and nutritional performance of $O$. niloticus fingerlings with increasing inclusion of $C$. olitorius seeds $(P<0.05)$. Significant increase in packed cell volume, white blood cell and haemoglobin were observed in treated $O$. niloticus fingerlings and there was no adverse effect of $C$. olitorius seeds on the haematological parameters of the fish. The study showed that $C$. olitorius seed at $1.5 \mathrm{~g} / 100 \mathrm{~g}$ significantly improved survival rate, weight gain and feed conversion ratio as well as reduced mortalities in the treated groups.
\end{abstract}

\section{Introduction}

In recent times, there has been a recurring problem of qualitative and affordable supply of livestock feeds which is directly related to the rising cost of conventional feedstuff which are in short supply and unavailable leading to higher cost of livestock products (Sarkiyay, 2010). In fish culture systems, feeding accounts for about $40 \%-60 \%$ of production costs (NRC 1993; Fagbenro et al., 2003) and the viability of a fish farm is largely dependent on the use of suitable feed. Feed additives as natural growth promoters are extensively researched in aquaculture because they are considered to be ecologically safer alternative to their synthetic counterparts (Isman, 2006) Medicinal plants as natural growth enhancers have been reported to significantly improve body weight, survival and feed conversion rates in fish (El Dakar, 2004; Shalaby, 2004). Feed additives in diets of cultured fish are being exploited with the aim of improving fish performance, immunity and carcass quality. A continuous search for new feed additives is therefore important for researchers in aquaculture (Cho and Lee, 2012).

The Nile tilapia (Oreochromis niloticus) belongs to the family Cichlidae and are widely cultivated for their ability to efficiently use natural aquatic foods, propensity to consume a variety of supplementary feeds, omnivorous food habits, resistance to diseases and handling, ease of reproduction in captivity, and tolerance to wide ranges of environmental conditions (Fagbenro, 1987). O. niloticus has high reproductive and growth rate, relatively disease free, scaly and hardy in 
nature (Satya and Timothy, 2004). Tilapia culture is widely practiced in Nigeria and contributes to food security, poverty alleviation, employment, trade and income generation (Omotosho and Fagbenro, 2005).

Corchorus olitorius belongs to the genus of about 40-100 species of flowering plant belonging to the family tiliaceae. $C$. olitorious is also known as long-fruited jute, tossa jute, jute mallow and Jew's mallow. In Nigeria, the plant is locally called Ahihara by the Igbo, Ewedu by the Yoruba and Malafiya by the Hausa (Ogunkanmi et al., 2010). It is an erect, annual herb growing up to $3.5 \mathrm{~m}$, an abundant agricultural product and a potential alternate feed ingredient (Tindall, 1993). It contains about $16 \%$ Crude Protein (Ndlovu and Afolayan, 2008). The leaves are widely used as a leafy vegetable in many Asian, African and European countries (Furumuto et al., 2002; Zeghichi et al., 2003). The leaves are demulcent, diuretic, febrifuge and also serve as tonic. The leaves have got attention from food and medical industry (Oyedele et al., 2006; Dewanjee et al., 2013). C. olitorius leaves have been reported to be very effective in the treatment of skin diseases such as measles and rashes (Mowobi et al., 2016).

Aqueous extracts of the seeds of $C$. olitorious have been reported to possess peripheral, anti-inflammatory and anti-pyretic activities (Zakaria et al, 2006) while antibacterial activities have also been reported from its methanolic extracts (Pal et al., 2006). There has also been reports by Ibrahim and Fagbohun (2011) that the seed oil of $C$. olitorius possess antimicrobial properties and can potentially be used as a food preservative as well as for medicinal purposes. Oloye et al., (2014) observed that $C$. olitorious seeds have largely been neglected and wasted and are primarily used for propagation. Adebooye et al. (2005) observed that wasting of $C$. olitorius seeds can arise as a result of the practice of leaving fruits on the plant for too long, such that some fully ripe inflorescences burst and shed their seeds. The wastage of $C$. olitorius seeds in the process of harvesting the leaves may be due to lack of popular knowledge about the nutritional content of the seeds as well as a lack of research interest (Isuosuo et al., 2019).

There is a dearth of information on the use of Corchorus olitorius in the diet of $O$. niloticus. This necessitated the present research to evaluate the effect of $C$. olitorius seed on growth, nutrient utilization and hematological parameters of $O$. niloticus fingerlings.

\section{Materials and Methods}

\section{Formulation of Experimental Diet}

Dried seeds of Corchorus olitorius were purchased from a local market, Oja-Oba in Akure, Ondo state, Nigeria. Identification and authentication of the seeds were done at the Department of Crop, Soil and Pest Management, Federal University of Technology Akure. The seeds were reduced to powdery form using Kenwood electric blender BL440 (UK). Amounts of 0 (control), $0.5,1.0,1.5$ and $2.0 \mathrm{~g}$ of $C$. olitorius seed powder per $100 \mathrm{~g}$ of feed were taken and mixed with a basal diet (30\% Crude protein), containing fish meal, yellow maize, soybean meal, fish oil, vegetable oil, vitamin premix and binder (starch). All dietary ingredients were milled. The ingredients were thoroughly mixed in a Hobart A-2007 (Hobart Ltd, London, UK) pelleting and mixing machine to obtain a homogeneous mass. The resultant mash was pressed without steam through a mixer with $2 \mathrm{~mm}$ diameter die attached to the Hobart pelleting machine. The pellets produced were dried at ambient temperature $\left(27-30^{\circ} \mathrm{C}\right)$, broken up, sieved and kept in a cool and dry place until the start of the feeding experiment (Table 1).

Table 1. Gross Composition of Experimental Diets Expressed in g/100g.

\begin{tabular}{|c|c|c|c|c|c|}
\hline \multicolumn{6}{|c|}{ EXPERIMENTAL DIETS } \\
\hline Ingredients & CTR & T1 & $\mathrm{T} 2$ & T3 & T4 \\
\hline Fish meal (72\%) & 15 & 15 & 15 & 15 & 15 \\
\hline Yellow maize $(10 \%)$ & 25 & 25 & 25 & 25 & 25 \\
\hline Soyabean meal (42\%) & 45 & 45 & 45 & 45 & 45 \\
\hline Fish oil & 4 & 4 & 4 & 4 & 4 \\
\hline Vegetable oil & 6 & 6 & 6 & 6 & 6 \\
\hline Vitamin premix* & 3 & 3 & 3 & 3 & 3 \\
\hline Binder (Starch) & 2 & 2 & 2 & 2 & 2 \\
\hline Corchorus olitorius seeds & 0 & 0.5 & 1.0 & 1.5 & 2.0 \\
\hline \multicolumn{6}{|l|}{ Proximate composition (\%) } \\
\hline Fish meal (72\%) & 15 & 15 & 15 & 15 & 15 \\
\hline Yellow maize (10\%) & 25 & 25 & 25 & 25 & 25 \\
\hline Soyabean meal (42\%) & 45 & 45 & 45 & 45 & 45 \\
\hline Fish oil & 4 & 4 & 4 & 4 & 4 \\
\hline Vegetable oil & 6 & 6 & 6 & 6 & 6 \\
\hline Vitamin premix* & 3 & 3 & 3 & 3 & 3 \\
\hline
\end{tabular}

Vitamin Premix content: Vitamin A 4,000,000IU, Vitamin D3 800,000IU, Vitamin K3 1,600mg, Vitamin B1 4,000mg, Vitamin B2 3,000mg, Vitamin B6 $3,800 \mathrm{mg}$, Vitamin B12 3mcg, Nicotonic acid 18,000mg, Pantothenic acid 8,000mg, Folic acid 800mg, Biotin 100mcg, Choline chloride $120,000 \mathrm{mg}$, Iron 8,000mg, Copper 800mg, Manganese 6,000mg, Zinc 8,000mg, lodine 400mg, Selenium 40mcg, Vitamin C(coated) 60,000mg, Inositol 10,000mg, Cobalt 150mg, Lysine 10,000mg, Methionine 10,000mg and Antioxidant 25,000mg. 


\section{Experimental Procedure}

This study was carried out in fifteen plastic tanks $\left(40 \times 30 \times 35 \mathrm{~cm}^{3}\right)$ at the Teaching and Research Laboratory of the Department of Fisheries and Aquaculture Technology, Federal University of Technology, Akure. The experiment consists of five dietary treatments (CTR, T1, T2, T3 and T4) set up in triplicates at a stocking density of ten fish per tank. Fish were fed $5 \%$ body weight twice daily (between 08:0009:00hr and 16:00-17:00hrs). All fish were batchweighed fortnightly and feeding rates adjusted accordingly. The experiment lasted for 56 days. At the end of the feeding experiment, the following growth and nutrient utilization parameters were determined;

Weight Gain =final weight of fish-the initial weight of fish

Percentage Weight Gain $=$ Final mean weight of fish $\times 100$ Initial mean weight of fish

$$
\text { Specific Growth Rate }=\frac{100\left(\ln W_{2}-\ln W_{1}\right)}{t}
$$

Where; $W_{1}$ and $W_{2}$ are the initial and final fish weight, respectively, and $t$ represents the duration of the feeding trial.

$$
\text { Percentage survival }=\mathrm{N}_{1} / \mathrm{N}_{0} \times 100
$$

Where: $\mathrm{N}_{1}=$ Total number of fish survival in pond at end of experiments.

$\mathrm{N}_{0}=$ Total number of fish in tank at the beginning of experiments.

$$
\text { Feed Conversion Ratio }=\frac{\text { dry weight of feed intake }(g)}{\text { Wet weight gain by fish }(g)}
$$$$
\text { Protein Efficiency Ratio (PER) }=\frac{\text { Weight gain }(g)}{\text { Protein fed }(g)}
$$

Haematological assessment was carried out on $O$. niloticus fed $C$. olitorius supplemented diets. Blood samples were collected through the vertebral blood vessels towards the caudal peduncle. Separate heparinized syringes treated with ethylene-diamineacetic acid (EDTA) were used for each fish. Blood samples were collected in urinalysis bottles and taken to the Central Research Laboratory, FUTA for analyses using the methods described by Svobodova et al., (1991). Blood indices that were analysed are:

\section{Red Blood Cells Count (RBC)}

Haemocytometer was used in blood cell counts. Counting of the blood cells was done in the counting chamber of the haematocytometer with the aid of compound microscope and was calculated as;

RBC (Erythrocyte count) $=$ No. of cells counted $x 5 \times 10 x$ $200\left(10^{6} \mathrm{~mm}^{3}\right)$

\section{Haemoglobin Estimation (Hb)}

Haemoglobinometer was used for Haemoglobin estimation

$$
\text { Haemoglobin }=\frac{\text { Value obtained }}{100} \times 17.2(\mathrm{gm} / 100 \mathrm{ml})
$$

\section{Mean Cell Haemoglobin Concentration (MCHC)}

This was calculated by dividing the haemoglobin content in $\mathrm{g} / 100 \mathrm{ml}$ using $\mathrm{PCV} / 100$ litre of red blood according to the formula:

$$
\mathrm{MCHC}(\mathrm{g} / \mathrm{dl})=\frac{\mathrm{Hb}}{\mathrm{PCV}} \times 100
$$

\section{Mean Corpuscular Haemoglobin (MCH)}

$\mathrm{MCH}$ was calculated from haemoglobin value $(\mathrm{Hb})$ and the erythrocyte (Er); expressed in picogramme (pg)

$$
\mathrm{MCH}=\frac{\mathrm{Hb}}{\mathrm{RBC}} \times 10
$$

\section{Mean Corpuscular Volume (MCV)}

This was calculated from the haematocrit value (PCV) \% and erythrocyte (Er) $10^{6} / \mathrm{mm}^{3}$ and its being expressed in flowlitre $(f I)$.

$$
\mathrm{MCV}=\frac{\mathrm{PCV}}{\mathrm{RBC}} \times 10
$$

\section{Packed Cell Volume (PCV) (Haematocrit)}

The PCV was determined by using microhaematocrit reader and expressed in percentage (\%).

\section{Total Leucocyte Count (TLC) or White Blood Cells}

This was calculated according to the method described by Dacie and Lewis (1991)

TLC $=$ Total number of cells in large squares $\times 500$ $\left(\mathrm{mm}^{3}\right)$ of blood. Its expressed in cubic millimeter $\left(\mathrm{mm}^{3}\right)$.

Proximate Analyses of $C$. olitorius seeds as well as experimental diets and fish were as described by AOAC (2005).

Water quality parameters during the experiment varied as follows; dissolved oxygen, $4.93-6.03 \mathrm{mg} / \mathrm{l}$; temperature $26.73-27.10^{\circ} \mathrm{C}$ and $\mathrm{pH} 6.63-6.72$. These water quality parameters are within the recommended ranges for O. niloticus (Viveen et al., 1986). 


\section{Statistical Analysis}

The effect of $C$. olitorius on growth and nutrient utilization as well as haematological parameters of $O$. niloticus were analysed using one-way analysis of variance and significant differences among treatments were compared using Duncan Multiple Range Test.

\section{Results and Discussions}

The proximate composition of $C$. olitorius seeds is presented in Table 2. Corchorus olitorius seeds have a Crude Protein content of $19.27 \pm 0.24 \%$, Crude fibre of $9.13 \pm 0.49 \%$, Ash of $7.05 \pm 0.13 \%$, Moisture content of $3.06 \pm 0.11 \%$ and Fat content of $16.76 \pm 0.31 \%$. The result for crude protein of $C$. olitorius seeds in this study is lower than that reported by Oloye et al., (2014) for wild seeds of $C$. olitorius. This suggests that $C$. olitorius seeds can be used as an additive in fish diets.

The present study showed an improvement in growth and feed utilization parameters for all fish groups fed $C$. olitorius seed powder at all levels. This indicates that the inclusion of $C$. olitorius seed powder in the experimental diets improved the fish growth positively.

Significantly highest weight gain, specific growth rate, survival as well as the best FCR were observed in fish group fed diet containing $1.5 \mathrm{~g} / 100 \mathrm{~g} C$. olitorius seed powder (T4) while the least values for weight gain, SGR and the poorest FCR were recorded in fish fed control diet (T1). These results agree with those reported by Dada et al., (2019) in C. gariepinus fed diets supplemented with $C$. olitorious seed powder. Similar results were also reported by Afe et al., (2019) in Heterobranchus bidorsalis fed dietary Ocimum gratissimum leaf powder. Dada and Abiodun (2014) also reported similar result in Oreochromis niloticus fingerlings fed dietary fluted pumpkin (Telfaria occidentalis) extract which showed significantly improved growth performance and feed utilization indices over the control group. The reports of Turan (2006) also align with those of the present study when Trifolium pratense was used as a growth-promoter in the diet of Oreochromis aureus. This study showed that C. olitorious supplementation in the diets of $O$. niloticus generally enhances nutrient utilization, as reflected by the improvements in weight gain, food conversion ratio, specific growth rate and protein efficiency ratio. This suggests that supplementation of fish diets with $C$. olitorious optimized protein use for the growth which can decrease the quantity of feed necessary for fish growth and hence, production costs.

The proximate composition of the experimental fish prior to feeding is presented in Table 4. O. niloticus fingerlings used in the experiment has a crude protein content of $52.15 \pm 0.03 \%$, ash content of $29.97 \pm 0.15 \%$ and fat content of $5.27 \pm 0.15 \%$. The proximate composition of the experimental fish fed the experimental diets is presented in Table 4. Significantly higher values $(P \leq 0.05)$ were observed for crude protein in fish fed $C$. olitorius seeds supplemented diets over the control group (T1). The highest protein content $59.33 \pm 0.13 \%$ was recorded in fish fed diet containing $1.0 \mathrm{~g} / 100 \mathrm{~g} \mathrm{C}$. olitorius seeds (T3) while the lowest protein content $(57.58 \pm 0.01 \%)$ was recorded in fish fed control diet (T1). The highest ash content $(23.03 \pm 0.01 \%)$ was recorded in fish fed control diet (T1) and the lowest ash content $(20.32 \pm 0.02 \%)$ was recorded for fish fed $1.0 \mathrm{~g} / 100 \mathrm{~g}$ of $C$. olitorius seed supplemented diet (T3). Crude lipid was found to be highest $(16.01 \pm 0.01 \%)$ in fish

Table 2. Proximate compositions of Corchorus olitorius seeds

\begin{tabular}{lc}
\hline Parameters & Percentage composition (\%) \\
\hline Moisture content & $3.06 \pm 0.11$ \\
Ash & $7.05 \pm 0.13$ \\
Crude lipid & $16.76 \pm 0.31$ \\
Crude fibre & $9.13 \pm 0.49$ \\
Crude protein & $19.27 \pm 0.24$ \\
NFE & $44.73 \pm 0.72$ \\
\hline
\end{tabular}

NFE: Nitrogen free extract

Table 3. Growth Performance and Feed Utilization of $O$. niloticus Fingerlings Fed with Experimental Diets

\begin{tabular}{lccccc}
\hline \multicolumn{5}{c}{ TREATMENT } \\
\hline Parameters & T1 & T2 & T3 & T4 & T5 \\
Initial mean weight(g) & $9.35 \pm 0.01$ & $9.35 \pm 0.00$ & $9.35 \pm 0.01$ & $9.35 \pm 0.00$ & $9.35 \pm 0.01$ \\
Final mean weight (g) & $12.73 \pm 0.01^{\mathrm{a}}$ & $12.82 \pm 0.01^{\mathrm{a}}$ & $13.57 \pm 0.02^{\mathrm{b}}$ & $14.30 \pm 0.01^{\mathrm{c}}$ & $13.46 \pm 0.04^{\mathrm{b}}$ \\
Mean weight gain (g) & $3.38 \pm 0.01^{\mathrm{a}}$ & $3.47 \pm 0.01^{\mathrm{a}}$ & $4.23 \pm 0.01^{\mathrm{b}}$ & $4.95 \pm 0.01^{\mathrm{c}}$ & $4.11 \pm 0.03^{\mathrm{b}}$ \\
SGR (\%) & $0.55 \pm 0.00^{\mathrm{a}}$ & $0.56 \pm 0.00^{\mathrm{a}}$ & $0.67 \pm 0.00^{\mathrm{b}}$ & $0.76 \pm 0.00^{\mathrm{c}}$ & $0.65 \pm 0.01^{\mathrm{b}}$ \\
FCR & $1.40 \pm 0.00^{\mathrm{b}}$ & $1.40 \pm 0.00^{\mathrm{b}}$ & $1.35 \pm 0.00^{\mathrm{a}}$ & $1.32 \pm 0.00^{\mathrm{a}}$ & $1.40 \pm 0.00^{\mathrm{b}}$ \\
PER & $0.61 \pm 0.00^{\mathrm{a}}$ & $0.64 \pm 0.00^{\mathrm{b}}$ & $0.76 \pm 0.00^{\mathrm{d}}$ & $0.86 \pm 0.00^{\mathrm{e}}$ & $0.73 \pm 0.01^{\mathrm{c}}$ \\
Survival (\%) & $86.45 \pm 0.22^{\mathrm{ab}}$ & $84.22 \pm 0.22^{\mathrm{ab}}$ & $86.67 \pm 0.00^{\mathrm{b}}$ & $89.67 \pm 0.85^{\mathrm{b}}$ & $79.78 \pm 0.22^{\mathrm{a}}$ \\
\hline
\end{tabular}

SGR = Specific growth rate, FCR = Feed conversion ratio and PER = Protein efficiency ratio. Figures on the same row having the same superscripts are not significantly different $(P>0.05)$ 
Table 4. Proximate Composition of the Experimental Fish Fed C. olitorius Supplemented Diets (on dry matter basis)

\begin{tabular}{lcccccc}
\hline \multicolumn{1}{c}{ TREATMENTS } \\
\hline Parameters & Initial & T1 & T2 & T3 & T4 \\
Moisture & $6.50 \pm 0.17$ & $4.86 \pm 0.04^{\mathrm{b}}$ & $4.87 \pm 0.04^{\mathrm{b}}$ & $4.02 \pm 0.01^{\mathrm{c}}$ & $3.41 \pm 0.01^{\mathrm{d}}$ & $5.03 \pm 0.01^{\mathrm{a}}$ \\
Ash & $29.97 \pm 0.15$ & $23.03 \pm 0.01^{\mathrm{d}}$ & $22.99 \pm 0.01^{\mathrm{d}}$ & $20.32 \pm 0.02^{\mathrm{a}}$ & $21.29 \pm 0.01^{\mathrm{b}}$ & $21.97 \pm 0.01^{\mathrm{c}}$ \\
Crude lipid & $5.27 \pm 0.15$ & $14.30 \pm 0.02^{\mathrm{a}}$ & $14.06 \pm 0.03^{\mathrm{a}}$ & $16.01 \pm 0.01^{\mathrm{b}}$ & $16.01 \pm 0.01^{\mathrm{b}}$ & $14.31 \pm 0.01^{\mathrm{a}}$ \\
Crude protein & $52.15 \pm 0.03$ & $57.58 \pm 0.01^{\mathrm{a}}$ & $57.96 \pm 0.06^{\mathrm{b}}$ & $59.33 \pm 0.13^{\mathrm{c}}$ & $59.20 \pm 0.14^{\mathrm{c}}$ & $58.15 \pm 0.01^{\mathrm{b}}$ \\
NFE & $6.12 \pm 0.32$ & $0.23 \pm 0.07^{\mathrm{ab}}$ & $0.12 \pm 0.02^{\mathrm{a}}$ & $0.32 \pm 0.15^{\mathrm{ab}}$ & $0.43 \pm 0.20^{\mathrm{ab}}$ & $0.54 \pm 0.04^{\mathrm{b}}$ \\
\hline
\end{tabular}

NFE: Nitrogen free extract.

Figures on the same row having the same superscripts are not significantly different $(P>0.05)$

Table 5. Some Haematological Parameters of $O$. niltoticus Fingerlings fed $C$. olitorious Seed supplemented Diets

\begin{tabular}{lccccc}
\hline \multicolumn{5}{c}{ TREATMENT } \\
\hline Parameters & T1 & T2 & T3 & T4 & T5 \\
PCV (\%) & $24.00 \pm 0.12^{\mathrm{a}}$ & $24.20 \pm 0.17^{\mathrm{b}}$ & $24.27 \pm 0.12^{\mathrm{b}}$ & $25.20 \pm 0.12^{\mathrm{c}}$ & $24.23 \pm 0.15^{\mathrm{b}}$ \\
HB (g/dl) & $8.03 \pm 0.09^{\mathrm{a}}$ & $8.17 \pm 0.09^{\mathrm{b}}$ & $8.20 \pm 0.09^{\mathrm{cb}}$ & $8.33 \pm 0.09^{\mathrm{c}}$ & $8.13 \pm 0.09^{\mathrm{ab}}$ \\
WBC $10^{3}\left(\mathrm{~mm}^{3}\right)$ & $7.20 \pm 0.12^{\mathrm{b}}$ & $8.40 \pm 0.12^{\mathrm{c}}$ & $8.13 \pm 0.09 \mathrm{c}$ & $8.90 \pm 0.06^{\mathrm{d}}$ & $6.20 \pm 0.06^{\mathrm{a}}$ \\
RBC $\times 10^{6}\left(\mathrm{~mm}^{3}\right)$ & $2.65 \pm 0.00^{\mathrm{a}}$ & $2.75 \pm 0.00^{\mathrm{c}}$ & $2.75 \pm 0.00^{\mathrm{c}}$ & $2.75 \pm 0.00^{\mathrm{c}}$ & $2.68 \pm 0.02^{\mathrm{b}}$ \\
MCV (fl) & $90.57 \pm 0.44^{\mathrm{a}}$ & $88.00 \pm 0.68^{\mathrm{a}}$ & $88.25 \pm 0.57^{\mathrm{a}}$ & $91.63 \pm 0.42^{\mathrm{a}}$ & $90.32 \pm 1.09^{\mathrm{a}}$ \\
MCHC (pg) & $33.47 \pm 0.29^{\mathrm{a}}$ & $33.76 \pm 0.52^{\mathrm{a}}$ & $33.78 \pm 0.34^{\mathrm{a}}$ & $33.07 \pm 0.47^{\mathrm{a}}$ & $33.57 \pm 0.56^{\mathrm{a}}$ \\
MCH (\%) & $30.31 \pm 0.33^{\mathrm{a}}$ & $30.32 \pm 0.35^{\mathrm{a}}$ & $29.93 \pm 0.35^{\mathrm{a}}$ & $30.30 \pm 0.32^{\mathrm{a}}$ & $30.31 \pm 0.22^{\mathrm{a}}$ \\
\hline
\end{tabular}

Means in a given column with the same superscript letter were not significantly different at $\mathrm{P}<0.05$.

Keys: PCV=Packed Cell Volume, $\mathrm{Hb}=$ Haemoglobin Estimation, WBC=White Blood Cell Count, RBC=Red Blood Cell Count

fed fed $1.0 \mathrm{~g} / 100 \mathrm{~g}$ and $1.5 \mathrm{~g} / 100 \mathrm{~g}$ C. olitorius seed supplemented diets (T3 and T4). respectively. The significant increase observed in crude lipid and crude protein contents of fish fed diets containing $C$. olitorius seed powder in this study suggests improvements in protein synthesis attributable to the presence of C. olitorious seed powder in the diet.

The haematological parameters of $O$. niltoticus (Table 5) showed significant differences $(P \leq 0.05)$ in packed cell volume (PCV), red blood cell (RBC), haemoglobin $(\mathrm{Hb})$ and white blood cells (WBC) concentrations in all the treatments. The PCV of $24.00-$ $25.20 \%$ falls within the range of $20-50 \%$ reported by Pietse et al. (1981). This agrees with the reports of Adegbesan et al. 2018 where significantly higher of heamatological parameters were observed in Clarias gariepinus fed Aloe barbadensis leaf diets. The increment observed in WBC in fish fed $1.0-1.5 \mathrm{~g} / 100 \mathrm{~g} C$. olitorious diet could indicate increased production of leucocytes in the liver tissues (Adegbesan et al., 2018). The range of $\mathrm{RBC}\left(2.65-2.75 \times 10^{6} \mathrm{~mm}^{3}\right)$ recorded in this study is comparable with $2.07-3.47 \times 10^{6} \mathrm{~mm}^{3}$ reported by lbidunni et al. (2017) when C. gariepinus was fed with Zingiber officinale root supplemented diets. Reduction in the RBC observed in fish fed T5 $(2.0 \mathrm{~g} / 100 \mathrm{~g}$ C. olitorius) could be due to higher concentration of ant-metabolites especially tannin (Ibidunni et al., 2018). There were no significant variations observed in $\mathrm{MCH}, \mathrm{MCV}$ and $\mathrm{MCHC}$ in fish fed $C$. olitorius seed powder.

\section{Conclusion}

The results from this present study suggest that $C$. olitorius seeds can be considered as a dietary supplement at an inclusion level of $1.5 \mathrm{~g} / 100 \mathrm{~g}$ in the diet of $O$. niloticus to enhance growth performance and blood parameters.

\section{Ethical Statement}

The Oreochromis niloticus fingerlings used for the study were humanely handled in accordance with the ethics and regulations guiding the use of research animals as approved by the university.

\section{Funding Information}

No funding information is available.

\section{Author Contribution}

OEA and AAD suggested, planned, and designed the study, MLS performed the experiments. The supervision of the experiments and report writing was performed by OEA. OEA wrote and edited the manuscript. AAD corrected and approved the final manuscript.

\section{Conflict of Interest}

The authors declare that they have no known competing financial or non-financial, professional, or personal conflicts that could have appeared to influence the work reported in this paper.

\section{Acknowledgement}

The authors are grateful to the Fisheries and Aquaculture Teaching and Research Farm, Obakekere, Federal University of Technology, Akure, Ondo state, 
Nigeria for providing the fish and space used for the feeding trials.

We also thank Dr. O.K. Gbadamosi and Mr. I.O. Oke of the Department of Fisheries and Aquaculture Technology, Federal University of Technology Akure, Ondo State, Nigeria for his advice and inputs during the course of the research work.

\section{References}

Adebooye, O.C., Ajayi, S.A., Baidu-Forson, J.J. and Opabode, J.T. (2005). Seed Constraint to Cultivation and Productivity of African Indigenous Leaf Vegetables. African Journal of Biotechnology, 4: 1480-1484.

Adegbesan, S.I., Obasa, S.O. and Abdulraheem, I. (2018) Growth Performance and Histopathology of African Catfish (Clarias gariepinus) Fed Varying Levels pf Aloe barbadensis Leaves. Journal of Fisheries, 6 (1): 553-562.

Afe, O.E., Dada, A.A. and Olufayo, M.O. (2019) Effects of Varying Levels of Ocimum gratissimum Leaf Powder on Growth Performance and Feed Utilization of Heterobranchus bidorsalis Fingerlings. African Journal of Fisheries and Aquatic Resources Management. 4: 35-42.

AOAC (Association of Official Analytical Chemists) (2005). Official methods of analysis. (18 ${ }^{\text {th }}$ ed.). Gaithersburg, MD: Association of Official Analytical Chemists International: $141 \mathrm{pp}$.

Cho, S.H. and Lee, S.M., (2012). Onion Powder in the Diet of the Olive Flounder, Paralichthys olivaceus: Effects on the Growth, Body Composition, and Lysozyme Activity. Journal of World Aquaculture Society 43, 30-38.

Dacie, S.I.V. and Lewis, S.M. (1991) Practical Hematology (7th Edition) J. and A. Churchill Ltd. Livingston, London Melborne and New York, pp. 67

Dada, A.A. and Abiodun, A.D. (2014) Effect of Dietary Fluted Pumpkin (Telfaria occidentalis) extract on Growth Performance, Body Composition and Hematological parameters of Nile Tilapia (Oreochromis niloticus Linnaeus). Journal of Fisheries. 2(3): 203-208.

Dada, A. A., Oke, I.O. and Adeniyi, A.L. (2019) Dietary Effect of Corchorus Olitorius Seeds on the Growth Performance of Clarias gariepinus Fingerlings. Proceedings of the $10^{\text {th }}$ FUTA-AGRIC Conference. Theme: Challenges of Sustainable Agriculture and Food Security Emerging Countries of Sub-Saharan Africa. $8^{\text {th }}-12^{\text {th }}$ July, 2019. Pp 499-504.

Dewanjee, S., Gangopadhyay, M., Sahu, R. and Karmakar, S. (2013). Cadmium Induced Pathophysiology: Prophylactic Role of Edible Jute (Corchorus olitorius) leaves with Special Emphasis on Oxidative Stress and Mitochondrial Involvement. Food Chemistry and. Toxicology. 60: 188198.

El-Dakar, A.Y. (2004): Growth response of hybrid tilapia, Oreochromis niloticus $x$ Oreochromis auraus to Diets Supplemented of Different Levels of Caraway Seeds. Agricultural Science. Mansoura University., 29 (11): 6083-6094

Fagbenro, O. A. (1987): A Review of Biological and Economical Principles Underlying Commercial Fish Culture Production in Nigeria. Journal of West African Fisheries 3: $171-177$.

Furumuto, T., Wang, R., Okazaki, K., Hasan, F.A.F.M. and Ali, I.M. (2002). Antitumour promoters in leaves of jute (Corchorus capsularis and Corchorus olitorius). Food
Science and Technological Research. 8: 239-243.

Ibidunni, A.S. Olubodun, O.S. and Ikililu, A. Metabolic Activities and Health Indices of African Catfish (Clarias gariepinus) Fed Varying Levels of Zingiber officinale Root. Journal of Applied Biology and Biotechnology, 5 (04): 021-028

Ibrahim, T.A. and Fagbohun, E.D. (2011). Physicochemical properties and in vitro anti-bacterial activity of Corchorus olitorius Linn. Seed oil. Life Sci. Leaflets, 15: 499-505.

Isman, M. (2006) Botanical Insecticides, Deterrents and Repellents in Modern Agriculture and an Increasingly Regulated World. Annual Review of Entomology 55: 4566.

Isuosuo, C.C., Akaneme, F.I. and Abu, N.E. (2019) Nutritional Evaluation of the Seeds of Corchorus olitorius: A Neglected and Underutilized Species in Nigeria. Pakistan Journal of Nutrition 18 (7): 692-703.

Mowobi, G. G., Abubakar, S., Osuji, C., Etim, V. N., Ogechi, N. and Egya, J.J. (2016) Ethnobotanical Survey of Medicinal Plants Used for the Treatment of Skin Disease in Keffi. Nigeria. American Journal of Phytomedicine and Clinical Therapeutics 4 (02) 073-090.

Ndlovu, J. and Afolayan, A.J. (2008). Nutritional analysis of the South African wild vegetable Corchorus olitorius L. Asian Journal of Plant Science. 7: 615-618.

National Research Council (NRC), (2011) Nutrient Requirements of Fish and Shrimps. National Academy Press, 376p.

Ogunkanmi, L.A., W.O. Okunowo, O.O. Oyelakin, B.O. Oboh, O.O. Adesina, K.O. Adekoya and Ogundipe, O.T. (2010) Assessment of genetic relationships between two species of jute plants using phenotypic and RAPD markers. International Journal of Botany, 6: 107-111.

Oloye, D.A., Odeja, O.T., Faboya E.T. and Ibrahim, T.A. (2014). Proximate and mineral composition of wild Corchorous olitorius seed flour. Res. Rev.: Journal Agriculture and Allied Science. 3: 1-4.

Omotoso, F.O. and Fagbenro, O.A. (2005) Social, economic and institutional impacts of aquaculture in Nigeria. World Aquaculture 36 (2): 15-17

Oyedele, D.J., Asonugho, C. and Awotoye, O.O. (2006). Heavy metals in soil and accumulation by edible vegetables after phosphate fertilizer application. Journal Agricultural and Food Chemistry. 5: 1446-1453

Pal, D.K., Mandal, M., Senthilkumar, G.P. and Padhiari, A. (2006). Antibacterial activity of Cuscuta reflexa stem and Corchorus olitorius seed. Fitoterapia, 77: 589-591.

Pietse, J.J., Smith, G.L. van Viiet, K.J., Schoobe, H.J and Hattingh, J. (1981). Some blood parameters of the Chunese grass carp, Ctenopharygodon idella (Valenciennes). South African Journal of Zoology 16(2): 124-126.

Sarkiyay, S., and Agar, T. M. (2010). Comparative Analysis on the nutritional and antinutritional contents of the sweet and bitter cassava varieties. Advance Journal of Food Science and Technology, 2(6), 328-334.

Satya, N. and Timothy, P. (2004). Tilapia Fish farming in Pacific Island countries (Vol. 1) Tilapia Hatchery Operation. Noumea, New Caledonia: Secretariat of the Pacific Community.Available (online) www.tilapia fish farming.com

Shalaby S.M.M. (2004): Response of Nile Tilapia, Oreochromis niloticus Fingerlings to Diets Supplemented with Different Levels of Fenugreek Seeds (Hulba). Journal of Agricultural Science, Mansoura University, 29: 2231- 
2242.

Svobodova, Z., Pravda, D and Palackova J. (1991) Unified Methods of Haemotological Examination of Fish. Vodary, Czechoslovakia. Research Unit of Fish Culture and Hydrobiology, 31pp.

Tindall, H. (1993). Vegetables in the Tropics. Hound Mills, Bsingstoke, Hampshire: The Macmillan Press Ltd. Pp 553.

Turan, F. (2006) Improvement of Growth Performance in Tilapia (Oreochromis aureus Linnaeus) by Supplementation of Red Clover (Trifolium Pratense) in Diets. The Israeli Journal of Aquaculture, 58(1), 34-38

Viveen, W., Richter, C., Van- Ordt, P., Janssen, J. and Huismsan, E. (1985) Practical Manual for the Culture of the African
Catfish (Clarias gariepinus). Directorate General for International Technical Cooperation, The Hague, The Netherlands, pp. 121.

Zakaria, Z.A., M.N. Somchit, H. Zaiton, A.M. Mat Jais and M.R. Sulaiman (2006). The in vitro antibacterial activity of Corchorus olitorius extracts. International Journal of Pharmacology, 2: 213-215.

Zeghichi, S., Kallithraka, S. and Simopoulos, A.P. (2003). Nutritional composition of molokhia (Corchorus olitorius) and stamnagathji (Cichorium spinosum). World Review of Nutrition and Dietetics. 91: 1-21. 